\title{
Pengantar editor-in-chief Mediapsi volume 7 nomor 2 tahun 2021
}

\author{
Ali Mashuri ${ }^{(1)}$ \\ (1) Jurusan Psikologi, Universitas Brawijaya, Malang, Indonesia
}

Mediapsi volume 7, number 2, December 2021 has published seven empirical articles. Each of the articles investigated multifarious topics. The first article is experimentation, which revealed that the career decision-making course (CDMC) was effective in reducing students' career decision making difficulties. The experiment in the second article demonstrated that self-disclosure training significantly increased the self-acceptance of adolescent students with cerebral palsy. The third article is qualitative research using a systematic review to identify and analyse various definitions and types of a case study. The fourth article examined fear of missing out (FoMO) and found that this variable, controlling for trait self-control, was suboptimal in explaining physical activity among Instagram users. The topic in the fifth article has to do with adolescents' emotional and behavioural problems. The findings in this article showed that male and female adolescents reported the same emotional and behavioural problems. The sixth article is a quantitative correlational study, which reported that among private school teachers, the lower the tenure, the more negative the relationship between job satisfaction and intentions to leave the organization or workplace. The seventh article is a correlational quantitative study that found how political trust, political efficacy, and candidate orientation played a significant role either simultaneously or partially in explaining political participation.

Keywords: difficulties in determining career, emotional and behavioural problems, fear of missing out (FoMO), political participation, self-disclosure training, turnover intentions

Tujuh artikel empiris telah dipublikasikan dalam Mediapsi edisi Desember 2021, volume 7 nomor 2. Topik yang dibahas dalam masing-masing artikel cukup bervariasi. Topik artikel pertama merupakan studi eksperimen dengan temuan bahwa career decision-making course (CDMC) efektif dalam mengurangi kesulitan siswa dalam menentukan karier mereka. Sementara itu, eksperimen dalam artikel kedua menunjukkan bahwa pelatihan pengenalan diri secara empiris berpengaruh signifikan dalam meningkatkan penerimaan diri siswa remaja dengan cerebral palsy. Artikel ketiga merupakan riset kualitatif yang menggunakan tinjauan sistematis untuk mengidentifikasi dan menganalisis berbagai macam definisi dan tipe studi kasus, Artikel keempat meneliti fenomena fear of missing out (FoMO) dan menemukan bahwa variabel tersebut kurang berperan signifikan dibandingkan dengan trait self-control dalam menjelaskan aktivitas fisik di kalangan pengguna media sosial Instagram. Topik dalam artikel kelima berkaitan dengan masalah emosi dan perilaku remaja. Temuan dalam artikel kelima menunjukkan bahwa remaja laki-laki dan remaja perempuan memiliki permasalahan emosi dan perilaku yang relatif sama. Artikel keenam merupakan studi kuantitatif korelasional, yang melaporkan bahwa di kalangan guru sekolah swasta, semakin rendah masa kerja maka hubungan antara kepuasaan kerja dan turnover intentions atau keinginan meninggalkan organisasi atau tempat kerja semakin negatif. Artikel ketujuh sekaligus terakhir merupakan studi kuantitatif korelasional yang menemukan bahwa kepercayaan politik, efikasi politik, dan orientasi kandidat berperan signifikan baik secara simultan maupun secara parsial dalam menjelaskan partisipasi politik.

Kata kunci: fear of missing out (FoMO), masalah emosi dan perilaku, partisipasi politik, penentuan karier, pengenalan diri, turnover intentions

MEDIAPSI, 2021, Vol. 7(2), 91-94, DOI: https://doi.org/10.21776/ub.mps.2021.007.02.1

Published online: $25-12-2021$

*Corresponding author: Ali Mashuri, Universitas Brawijaya, Malang, Indonesia. E-mail: alimashuri76@ub.ac.id

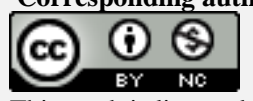

This work is licensed under a Creative Commons Attribution-NonCommercial 4.0 International License.

How to cite this article in accordance with the American Psychological Association (APA) $7^{\text {th }}$ guidelines:

Mashuri, A. (2021). Pengantar editor-in-chief Mediapsi volume 7 nomor 2 tahun 2021. MEDIAPSI, 7(2), 91-94. https://doi.org/10.21776/ub.mps.2021.007.02.1 
Dalam pengantar ini, editor-in-chief meringkas temuan-temuan utama tujuh artikel empiris yang telah dimuat di Mediapsi, volume 7 nomor 2, Desember 2021. Artikel pertama berfokus pada permasalahan sulitnya menentukan karier yang dialami oleh remaja sekolah menengah atas. Setelah menyelesaikan pendidikan mereka, harus diakui bahwa remaja sekolah menengah atas sering mengalami dilema dalam menentukan keputusan antara mencari atau mendapatkan kerja dan melanjutkan studi ke jenjang pendidikan yang lebih tinggi (Martincin \& Stead, 2015). Banyak faktor yang menjelaskan kesulitan remaja tersebut, mulai dari kepribadian, dukungan orang tua, dukungan teman sebaya dan guru (Fernandes \& Bance, 2015; Stărică, 2012). Artikel pertama bertujuan untuk menguji efektivitas career decisionmaking course (CDMC) sebagai intervensi untuk mengurangi kesulitan remaja sekolah menengah atas dalam menentukan karier mereka. Hasil penelitian dalam artikel pertama menunjukkan bahwa, membuktikan efektifitas intervensi, skor kesulitan penentuan karier pada 35 siswa sekolah menengah atas setelah intervensi (posttest) lebih rendah secara signifikan dibandingkan dengan skor kesulitan penentuan karier sebelum intervensi (pretest).

Artikel kedua bertujuan untuk menguji sejuah mana pelatihan pengenalan diri berpengaruh signifikan dalam meningkatkan penerimaan diri pada siswa remaja yang menderita cerebral palsy (CP). Latar-belakang penelitian dalam artikel kedua bersinggungan dengan kesulitan penerimaan diri yang dialami oleh penderita CP pada umumnya (EspínTello dkk., 2018) dan penderita CP pada remaja khususnya (Brossard-Racine dkk.,
2013) akibat kekurangan fisik yang mereka alami. Hasil eksperimentasi dalam artikel kedua mengonfirmasi efektivitas intervensi sehingga skor penerimaan diri partisipan setelah pemberian pelatihan (posttest) lebih tinggi secara signifikan daripada skor penerimaan diri partisipan sebelum pemberian pelatihan (pretest).

Artikel ketiga mengangkat topik tentang studi kasus, sebuah metode ilmiah yang sangat popular dalam penelitian kualitatif (Hyett dkk., 2014). Hasil penelitian dalam artikel ketiga mengungkap fakta adanya variasi definisi dan tipe-tipe studi kasus dalam berbagai macam literatur. Artikel keempat, sementara itu, menganalisis keterkaitan antara fear of missing out (FoMO), trait self-control, dan aktivitas fisik di kalangan pengguna media sosial Instagram. Di era digital saat ini, FoMO menjadi fenomena yang sangat jamak terjadi terutama di kalangan pengguna aktif media sosial (Tandon dkk., 2021), yang secara empiris berdampak negatif terhadap kualitas kehidupan sehari-hari dan produktifitas kerja (Rozgonjuk dkk., 2020). Temuan dalam artikel keempat menunjukkan bahwa FoMO berkorelasi negatif secara signifikan dengan aktivitas fisik pada responden penelitian. Meskipun demikian, korelasi negatif tersebut menjadi tidak signifikan setelah mengikutsertakan trait self-control sebagai prediktor aktivitas fisik.

Topik artikel kelima berkaitan dengan permasalahan emosi dan perilaku yang dialami oleh remaja laki-laki dan remaja perempuan. Tugas perkembangan utama remaja, baik perempuan maupun laki-laki, adalah menemukan dan mengembangkan identitas personal seiring dengan perubahan kognitif dan fisik yang menonjol yang mereka alami (Flouri \& 
Panourgia, 2014). Kesimpulan dalam artikel kelima menginformasikan bahwa remaja laki-laki dan remaja perempuan memiliki permasalahan perilaku berupa conduct disorder dan permasalahan emosi berupa peer problem yang relatif sama.

Artikel keenam merupakan studi korelasional dengan tujuan menguji peran masa kerja sebagai moderator hubungan antara kepuasan kerja dan turnover intentions atau intensi meninggalkan organisasi atau tempat kerja. Literatur memang menyebutkan bahwa guru termasuk pihak yang rawan mengalami turnover intentions, terutama guru yang merasakan burnout, yang mengajar di sekolah-sekolah yang mengalami kesulitan finansial, kurang berprestasi, dan kurang mendapatkan dukungan kepemimpinan dan kolega yang memadai (Kraft dkk., 2016; Madigan \& Kim, 2021; Simon \& Johnson, 2015). Hasil penelitian dalam artikel keenam mendukung hipotesis yang ditetapkan dimana hubungan ke arah negatif antara kepuasaan kerja dan turnover intentions lebih kuat dan signifikan pada guru dengan masa kerja yang rendah dibandingkan dengan guru dengan masa kerja yang cukup lama.

Artikel ketujuh sekaligus terakhir merupakan studi kuantitatif korelasional, dengan tujuan menguji faktor-faktor yang menjelaskan partisipasi politik. Di Indonesia, partisipasi politik dalam pemilihan umum (pemilu) eksekutif maupun legislatif relatif mengalami peningkatan semenjak demokrasi diterapkan untuk memilih calon pemimpin politik setelah masa Orde Baru berlalu (Ida dkk., 2020). Terutama di kalangan kaum muda, media digital sangat berpengaruh dalam meningkat partisipasi politik mereka (Lee, 2017; Saud \& Margono, 2021). Temuan dalam artikel ketujuh menunjukkan peran signifikan political trust, efikasi politik, dan orientasi kandidat baik secara bersama-sama atau simultan maupun secara parsial dalam menjelaskan partisipasi politik.

\section{Daftar Pustaka}

Brossard-Racine, M., Waknin, J., ShikakoThomas, K., Shevell, M., Poulin, C., Lach, L., ... \& Majnemer, A. (2013). Behavioral difficulties in adolescents with cerebral palsy. Journal of Child Neurology, 28(1), 27-33. https://doi.org/10.1177\%2F0883073 812461942

Espín-Tello, S. M., Dickinson, H. O., Bueno-Lozano, M., JiménezBernadó, M. T., \& CaballeroNavarro, A. L. (2018). Functional capacity and self-esteem of people with cerebral palsy. American Journal of Occupational Therapy, 72(3), 7203205120p1$7203205120 \mathrm{p} 8$.

https://doi.org/10.5014/ajot.2018.025 940

Fernandes, R., \& Bance, L. O. (2015). Pathway from adolescents' career indecision to career decision: Basis for career guidance program. Indian Journal of Positive Psychology, 6(2), 136-132.

https://doi.org/10.15614/ijpp\%2F201 5\%2Fv6i2\%2F73835

Flouri, E., \& Panourgia, C. (2014). Negative automatic thoughts and emotional and behavioural problems in adolescence. Child and Adolescent Mental Health, 19(1), 4651. https://doi.org/10.1111/camh.12004

Hyett, N., Kenny, A., \& Dickson-Swift, V. (2014). Methodology or method? A critical review of qualitative case 
study reports. International Journal of Qualitative Studies on Health and Well-Being, 9(1), $1-12$. https://doi.org/10.3402/qhw.v9.2360 6

Ida, R., Saud, M. \& Mashud, M. (2020). An empirical analysis of social media usage, political learning and participation among youth: a comparative study of Indonesia and Pakistan. Quality \& Quantity, 54, 1285-1297. https://doi.org/10.1007/s11135-02000985-9

Kraft, M. A., Marinell, W. H., \& ShenWei Yee, D. (2016). School organizational contexts, teacher turnover, and student achievement: Evidence from panel data. American Educational Research Journal, 53(5), 1411-1449. https://doi.org/10.3102\%2F0002831 216667478

Lee, S. H. (2017). Digital democracy in Asia: The impact of the Asian internet on political participation. Journal of Information Technology \& Politics, 14(1), 62-82. https://doi.org/10.1080/19331681.20 16.1214095

Madigan, D. J., \& Kim, L. E. (2021). Towards an understanding of teacher attrition: A meta-analysis of burnout, job satisfaction, and teachers' intentions to quit. Teaching and Teacher Education, 105, 1-14. https://doi.org/10.1016/j.tate.2021.10 3425

Martincin, K. M., \& Stead, G. B. (2015). Five-factor model and difficulties in career decision making: A metaanalysis. Journal of Career Assessment, 23(1), 3-19.
https://doi.org/10.1177\%2F1069072 714523081

Rozgonjuk, D., Sindermann, C., Elhai, J. D., \& Montag, C. (2020). Fear of Missing Out (FoMO) and social media's impact on daily-life and productivity at work: Do WhatsApp, Facebook, Instagram, and Snapchat Use Disorders mediate that association?. Addictive Behaviors. Advance online publication. https://doi.org/10.1016/j.addbeh.202 0.106487

Saud, M., \& Margono, H. (2021). Indonesia's rise in digital democracy and youth's political participation. Journal of Information Technology \& Politics, 1-12. https://doi.org/10.1080/19331681.20 21.1900019

Simon, N., \& Moore Johnson, S. (2015). Teacher turnover in high-poverty schools: What we know and can do. Teachers College Record, 117(3), 1-36. https://www.tcrecord.org/Content.as p?ContentId $=17810$

Stărică, E. C. (2012). Predictors for career indecision in adolescence. ProcediaSocial and Behavioral Sciences, 33, 168-172. https://doi.org/10.1016/j.sbspro.2012 .01 .105

Tandon, A., Dhir, A., Almugren, I., AlNemer, G. N., \& Mäntymäki, M. (2021). Fear of missing out (FoMO) among social media users: A systematic literature review, synthesis and framework for future research. Internet Research, 31(2), 782-821. https://doi.org/10.1108/INTR-112019-0455 